\title{
Utilisation of Biopolymer Combination as a Material for Making Gel Peel Off Mask
}

\author{
Ridwanto $^{1}$, Minda Sari Lubis ${ }^{2}$, Ricky Andi Syahputra ${ }^{3}$, Hanis Inriyani ${ }^{4}$ \\ \{rid.fillah66@gmail.com\} \\ Universitas Muslim Nusantara Al Washliyah ${ }^{1,2,3,4}$
}

\begin{abstract}
Utilisation of biopolymers combination as a material for making gel peel off masks has been carried out. The purpose of this research to determine the combination of biopolymers. It can be formulated in dosage form Gel peel off mask and find out that single and combination biopolymers have different viscosity effects in the preparation of gel peel off masks. Tests on the preparation of peel off gel masks include homogeneity test, organoleptic observation, $\mathrm{pH}$ measurement, determination of viscosity, time testing of the preparation dried up, stability observation and statistical analysis test with SPSS 16.0 software which includes viscosity stability test using ANOVA parametric analysis method (Analysis of Variance) and continued with Duncan's test. The results showed that each formula of peel off gel mask combined with a single biopolymer and a combination of biopolymers had a pH of $5.4-5.8$, viscosity $31790 \mathrm{cp}-38240 \mathrm{cp}$, and the time needed to dry up 21-27 minutes in storage for 12 weeks. The results of the statistical analysis of the viscosity stability test of the six formulas of peel off gel mask using ANOVA method showed a significant difference between each formula ( $\mathrm{P}$ value $<0.05)$. The combination of biopolymer in formula 5 (Chitosan $0.0625 \%+$ Xanthan gum $0.0625 \%$ ) in the preparation of peel-off gel mask gave a higher viscosity effect compared to other formulas
\end{abstract}

Keywords: Biopolymer, Chitosan, Gelling agent, gel peel off mask

\section{Introduction}

The skin is a cover's layer of the body and as a body protector from various kinds of dangers that come from outside. For women, the skin is a part of the body that needs special attention in terms of beauty, especially on the facial skin. This causes a lot of women who will always try to beautify themselves by using cosmetics (Wibowo, 2008).

Facial cosmetics which are commonly used are available in various dosage forms, one of which is in the form of a mask. Facial masks are cosmetic beauty treatments that are very popular for improving skin quality (Yeom et al., 2011). Mask products are practical in their use, one of which is wearing a peel off mask.

Peel off mask is a cosmetic form of gel-shaped facial skin care that is applied to the skin at a certain time. It will form a layer of elastic transparent film, after drying the mask can be directly lifted or released without rinsing (Hary, 1973). Physical quality gel facial mask peel off is influenced by the composition of the ingredients used, especially the composition of polyvinyl alcohol (PVA). PVA plays a role in giving the peeloff effect because it has adhesive properties so it can form a layer of film that is easily peeled off after drying (Birck et al., 2014). 
In this study, biopolymers were used as gelling agents. Biopolymer as a polymer that is formed naturally produced by living things such as plants, animals or microorganisms and is found in nature. Natural polymers have many advantages over artificial polymers. One of the advantages of natural polymers compared to synthetic polymers is their abundance. For example, cellulose is the most abundant natural polymer in nature, while chitin and chitosan are second only to cellulose (Yang, et al., 2008).

The biopolymers used in this study were Chi-tosan, Xanthan gum and Carboxymethyl cellulose (CMC). Chitosan is a polymer of saccharides (poly-saccharides) obtained from the deacetylation process of chitin compounds contained in the outer skin of animals of the Crustacean class, for example shrimp, crabs, and others (Tiyaboonchai, 2003). Chitosan has the ability to form gel, film and fiber, because of its high molecular weight and solubility in dilute acidic solutions (Suhardi, 1992). Xanthan gum is a natural polysaccharide and an important industrial biopolymer. Xanthan gum has three superior properties, which are a high viscosity at low concentrations, pseudoplastic, it is not sensitive to temperature, $\mathrm{pH}$ and electrolyte concentration. These three superior qualities make xanthan gum very important in the food, cosmetics, pharmaceutical, paper, paint, textile and adhesive industries (Jeeva, et al., 2011).

Carboxymethyl Cellulose (CMC) is a natural polymer derivative that is most widely used in vari-ous industries, such as food, pharmaceuticals, deter-gents, textiles and cosmetic products. This is be-cause $\mathrm{CMC}$ has certain functions as thickener, stabilizer, gelling agent, binder and emulsifier (Kamal, 2010). Carboxymethylcellulosa is widely used for oral and topical pharmaceutical formulations, mainly because of the level of viscosity it has as a gelling agent (Zath and Kushla, 1996).

Based on the background above, the researcher was interested in conducting research on the formu-lation of peel off gel mask with a combination of biopolymer namely Chitosan, Xanthan gum and Carboxymethyl cellulose (CMC) as gelling agents.

\section{Method}

This research method was conducted experimental-ly. The study included the manufacture of peel-off gel masks, using a single biopolymer namely Chi-tosan, Carboxymethyl cellulose (CMC), and Xan-than gum with a concentration of $0.125 \%$ while the combination of biopolymers with a concentration of $0.0625 \%: 0.0625 \%$. Examination of the preparation includes physical evaluation of the preparation (ho-mogeneity test, organoleptic observation, $\mathrm{pH}$ meas-urement, determination of viscosity, test time of preparation to dry) and observation of stability of the preparation made. And statistical analysis test with SPSS 16.0 software which includes viscosity stability test using ANOVA parametric analysis method (Analysis of Variance) and followed by Duncan test

\subsection{Instruments and materials}

\subsubsection{Instruments}

The instruments used include: analytical scales, wa-ter baths, spatulas, shovels, tissues, measuring cups (pyrex), beaker (pyrex), stirring rods, porcelain cups, peel off gel mask 
containers, transparent glass, Brookfield Viscometer and $\mathrm{pH}$ meters (Hanna) and glass objects..

\subsubsection{Materials}

Ingredients Materials used include: polyvinyl alco-hol, glycerin, propylene glycol, methyl paraben, propyl paraben, triethanolamine, alcohol 96\%, aquadest and biopolymers such as chitosan, xanthan gum, and carboxymethyl cellulose

\subsection{Formulation of gel peel off mask}

\subsubsection{Preparations standard formula for peel off gel mask}

The basic formula chosen for the manufacture of gel peel mask preparations is in this study with composition (Rieger, 2000).

\begin{tabular}{lll}
\hline $\mathrm{R} /$ & Polyvinyl alcohol & $5-10 \%$ \\
\cline { 2 - 3 } & Humectant & $2-10 \%$ \\
& Surfactant & $2-5 \%$ \\
Alcohol & $10-30 \%$ \\
pH buffer & $\mathrm{pH} 4-7$ \\
Preservative & $\mathrm{Qs}$ \\
Perfume & $\mathrm{Qs}$ \\
Coloring & $\mathrm{Qs}$ \\
Distilled water & $\mathrm{ad} 100$ \\
\hline
\end{tabular}

\section{2..2.2Biopolymer combination formula}

The Formula of Biopolymer Combination in table 1

Table 1. The formula design of the gelpeel off mask.

\begin{tabular}{lllllllll}
\hline No & Material & \multicolumn{2}{l}{ Formula $(\mathrm{g})$} & & & \\
\cline { 3 - 8 } & & F0 & F1 & F2 & F3 & F4 & F5 & F6 \\
1 & Chitosan & - & 0,125 & - & - & 0,0625 & 0,0625 & - \\
2 & Xanthan gum & - & - & 0,125 & - & 0,0625 & - & 0,0625 \\
3 & Carboxymethylcelul & - & - & - & 0,125 & - & 0,0625 & 0,0625 \\
& osa & & & & & & & \\
4 & Polyvinyl alkohol & 10 & 10 & 10 & 10 & 10 & 10 & 10 \\
5 & Glycerin & 10 & 10 & 10 & 10 & 10 & 10 & 10 \\
6 & Propylene glycol & 10 & 10 & 10 & 10 & 10 & 10 & 10 \\
7 & Methyl paraben & 0,20 & 0,20 & 0,20 & 0,20 & 0,20 & 0,20 & 0,20 \\
8 & Propilparaben & 0,03 & 0,03 & 0,03 & 0,03 & 0,03 & 0,03 & 0,03 \\
9 & Trietanolamine & 0,5 & 0,5 & 0,5 & 0,5 & 0,5 & 0,5 & 0,5 \\
10 & Etanol 96\% & 15 & 15 & 15 & 15 & 15 & 15 & 15 \\
11 & Aquadest & $\mathrm{ad} 100$ & $\mathrm{ad} 100$ & $\mathrm{ad} 100$ & $\mathrm{ad} 100$ & $\mathrm{ad} 100$ & $\mathrm{ad} 100$ & $\mathrm{ad} 100$ \\
\hline
\end{tabular}




\subsubsection{Procedure for making gel peel off mask}

In a glass beaker, polyvinyl alcohol (PVA) was add-ed with distilled water and glycerin, then heated on a water bath and stirred constantly to form a gel (Mass 1). Xanthan gum and aquadest were added to the evaporating dish to be stirred and heated (Mass 2). Propylene glycol was added to the beaker glass, methylparaben and propyl paraben were added, stirred until homogeneous (Mass 3). Mass 2 inserted to the mass 1, stirred homogeneously then entered mass 3 stirred homogeneously. The mixture solution was added triethanolamine stirred constantly and homogeneously. After cooling ethanol was added to form a homogeneous mass of peel off gel mask.

\subsubsection{Physical preparations evaluation of gel peel off mask}

Physical quality checks were carried out on each preparation. Physical quality checks include: homo-geneity test, organoleptic observation, $\mathrm{pH}$ measure-ment, determination of viscosity, the preparation dries testing and observations of the stability of the preparation made.

\subsubsection{Homogeneity test}

A certain number of preparations if applied to a piece of glass or other transparent material that is sufficient. The preparation must show a homogene-ous arrangement and there is no visible coarse grain (DG POM, 1979).

\subsubsection{Observation of organoleptic}

Organoleptic observation was carried out by observ-ing changes in shape, color, and odor from the prep-aration of gel peel off mask (Septiani, 2011)

\section{2..2.7pH measurement}

Determination of the $\mathrm{pH}$ of the preparation was done by using a $\mathrm{pH}$ meter. The tool was first calibrated using standard buffer solution ( $\mathrm{pH} 7.01)$ and acid $\mathrm{pH}$ buffer solution $(\mathrm{pH} 4.01)$ until the device shows the $\mathrm{pH}$ price. Then the electrode was washed with distilled water, then dried with tissue. The sample was made in $1 \%$ concentration, ie weigh $1 \mathrm{~g}$ of the preparation and dissolved in distilled water to $100 \mathrm{ml}$. Then the electrode was dipped in the solution. Let the tools showed the $\mathrm{pH}$ considered to be constant. The figure shown by $\mathrm{pH}$ meter is the $\mathrm{pH}$ of the preparation (Rawlins, 2003)

\subsubsection{Determination of viscosity}

A total of $100 \mathrm{ml}$ of gel inserted into a $250 \mathrm{ml}$ beak-er glass then the viscosity is measured with Brookfield Viscometer. Not only the spindle was set but also the speed to be used (Septiani, 2011). 


\subsubsection{Test time drying preparation}

Each mask formula was put into a plastic pot, stored at room temperature and measured stability parameters such as odor, color, $\mathrm{pH}$, time of preparation dried, and viscosity evaluated during 12 weeks storage with observations every 2 weeks (National Health Surveillance Agency , 2005)

\subsubsection{Data analysis}

The results of the viscosity stability test data were analyzed using statistical package processing for SPSS 16.0. The data input for statistical included normality test, homogeneity test, ANOVA (Analysis of Variance) test and continued with Duncan test.

\section{Result}

Preparation of gel-off mask is made using a standard gel-off mask mask formula (Rieger, 2000). This standard formula was modified when removed some material. The preparation of peel off gel masks is made in 6 formulas using different biopolymers. The biopolymers used to make peel off gel masks were Chitosan, Xanthan gum, and Carboxymethyl Cellulose (CMC). As blanks, peel-off gel masks without biopolymers were used. Each formulation of peel off gel mask was made with a single biopolymer and a combination of biopolymer. Biopolymer was single with a concentration of $0.125 \%$ while in the combination of biopolymers a concentration of $0.0625 \%$ : $0.0625 \%$ was used. The mask preparations were obtained in the form of peel off gel mask with clear and cream color.

\subsection{Physical quality preparations evaluation of peel off gel mask}

\subsection{Homogeneity test}

Homogeneity test is done by applying the prep-aration on a piece of glass or other transparent material, then leveling. If there are no granules then the preparation can be said to be homogeneous (DG POM, 1979).Test results of the homogeneity of gel peel off mask in Fig 1.

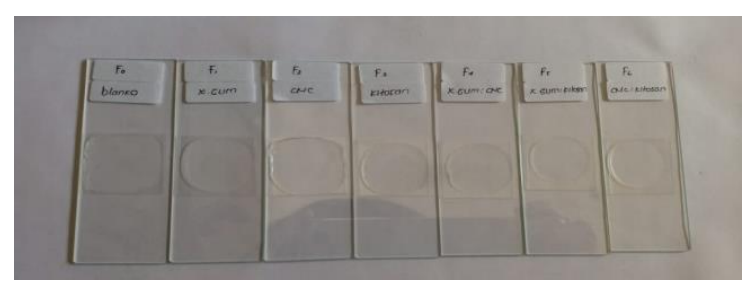

Fig 1. Test results of the homogeneity of gel peel off mask

The results of homogeneity examination on the preparation of peel off gel mask showed that all preparations did not show any coarse grains. It showed that the preparation had a homogeneous arrangement, as shown in Figure 2. 
Table 2. Observation results of homogeneity of GelPeelOff Mask preparations

\begin{tabular}{ll}
\hline Preparations & Homogeneity \\
F0 & Homogeneous \\
F1 & Homogeneous \\
F2 & Homogeneous \\
F3 & Homogeneous \\
F4 & Homogeneous \\
F5 & Homogeneous \\
F6 & Homogeneous \\
\hline
\end{tabular}

Information:

F0 = Formula without biopolymers

$\mathrm{F} 1=$ Formula Xanthan gum $0.125 \%$

F2 = Formula Carboxymethyl Cellulose $0.125 \%$

F3 = Chitosan Formula 0.125\%

F4 = Formula Xanthan gum $0.0625 \%$ + Carboxymethyl Cellulose $0.0625 \%$

F5 = Chitosan Formula $0.0625 \%+$ Xanthan gum $0.0625 \%$

F6 = Chitosan Formula 0.0625\% + Carboxymethyl Cellulose $0.0625 \%$

The results of organoleptic examination on F3 Gel Peel Off mask (Chitosan 0.25\%), F5 (Chitosan $0.0625 \%$ + Xanthan gum $0.0625 \%$ ) and F6 (Chitosan $0.0625 \%$ + Carboxymethyl Cellulose $0.0625 \%$ ) gave odor which was a little sour and creamy. This is due to the addition of acetic acid to dissolve chitosan because chitosan is slightly soluble in water and not soluble in ethanol (Rowe, et al., 2009). Chitosan is more soluble in acetic acid (Tang, et al., 2007).

\subsection{2 pH measurement}

$\mathrm{pH}$ preparation was carried out using a $\mathrm{pH}$ meter (Hanna instruments). The results can be seen in Ta-ble 3 below.

pH stability is an important parameter that de-termines whether a preparation is stable or not. $\mathrm{pH}$ testing aims to determine the safety of the prepara-tion when used. Thus, it did not irritate the skin (Anief, 2004). The $\mathrm{pH}$ test results on all peel off gel masks showed a $\mathrm{pH}$ of 5.4-5.8. The $\mathrm{pH}$ test results on the formula F2 (Carboxymethyl Cellulose $0.125 \%$ ) gave a more alkaline result of 5.7 while at F3 (chitosan) gave a more acidic result of 5.5. The pH of all formulas for the peel off gel mask is still in the normal $\mathrm{pH}$ range of the skin, which is between 4.5 and 7.0 (Wasita atmadja, 1997) 1997). 
Table 3. The results of the $\mathrm{pH}$ test observations of Peel Off Gel Mask preparations

\begin{tabular}{ll}
\hline Preparation & $\mathrm{pH}$ \\
\hline F0 & 5,4 \\
F1 & 5,6 \\
F2 & 5,7 \\
F3 & 5,5 \\
F4 & 5,8 \\
F5 & 5,7 \\
F6 & 5,7 \\
\hline
\end{tabular}

\subsubsection{Analysed of viscosity}

Viscosity examination was done using a brook field viscometer. The results can be seen in Table 4.

Table 4. The results of the viscosity test observations of Peel Off Gel Mask preparations preparation Viskositas (cp)

\begin{tabular}{ll}
\hline preparation & Viskositas (cp) \\
F0 & 11773 \\
F1 & 33350 \\
F2 & 31790 \\
F3 & 32440 \\
F4 & 33090 \\
F5 & 38240 \\
F6 & 37060 \\
\hline
\end{tabular}

The determination of the viscosity value of the preparation of peel off gel mask using xanthan gum, CMC, and chitosan biopolymers the viscosity of the gel was influenced by the concentration and proper-ties of the gelling agent. An increase in the amount of gelling agent can strengthen the gel matrix which causes an increase in viscosity (Zats and Kushla, 1996).

The viscosity value of the peel off gel mask preparation showed that the different viscosity val-ues in each formula ranged from $31790 \mathrm{Cp}-38240 \mathrm{Cp}$ which can be seen in Table 4.4. The viscosity value at F0 as blank gives a lower yield of $11773 \mathrm{Cp}$ because there was no addition of gelling agent or without biopolymer. The lowest viscosity was found in F2 (Carboxymethyl Cellulose $0.125 \%$ ) with 31790 Cps while the highest viscosity is found in F5 (Chitosan $0.0625 \%$ + Xanthan gum $0.0625 \%$ ) which is $38240 \mathrm{Cp}$. 


\subsubsection{Preparation time test results dry}

The test of the time the preparation dries was done by observing the time needed for the preparation to dry, ie the time from when the peel-off mask is applied to the skin of the arm with a length of $7 \mathrm{~cm}$ and width of $7 \mathrm{~cm}$. until a dry layer forms. The results can be seen in Table 5 .

The most influential factor on dry time is the concentration of ethanol in the formulation. Increasing ethanol concentration will shorten the dry time of the preparation, this is because ethanol has a higher level of volatility compared to pure water (Beringhs et al., 2013). The formulation of peel off gel mask formulation used $15 \%$ ethanol concentra-tion. It based on the formulation contained in Hary's Cosmeticology book which stated that ethanol concentration can be used up to $30 \%$ in the gel peel off mask.

Table 5. Observation results when drying Peel Off Gel Mask preparations

\begin{tabular}{ll}
\hline Preparation & Time to dry (minutes) \\
F0 & 23 \\
F1 & 25 \\
F2 & 24 \\
F3 & 25 \\
F4 & 27 \\
F5 & 29 \\
F6 & 29 \\
\hline
\end{tabular}

\subsubsection{Preparation stability check results}

The stability evaluation of the preparation was carried out during 12 weeks storage with observation interval every $2,4,6,8,10$, and 12 weeks. The preparation of peel-off gel mask was stored at room temperature and observed changes in odor, color, $\mathrm{pH}$, time of preparation to dry, and viscosity. The test results showed that the preparation of peel-off gel mask experienced changes during storage, where viscosity and preparation time to dry up increased. The results of the evaluation of the stability of each test parameter can be seen in Table 6 .

Table 6. Observation Results of Stability Test for Peel-off Mask Preparation Formula for Time Parameters (Weeks)

\begin{tabular}{lllcllll}
\hline $\begin{array}{l}\text { Formul } \\
\text { a }\end{array}$ & Parameters & \multicolumn{2}{l}{ Time (Weeks) } & & & & \\
& & 2 & 4 & 6 & 8 & 10 & 12 \\
\multirow{2}{*}{ F0 } & Color & TB & TB & TB & TB & TB & TB \\
& Smell & TB & TB & TB & TB & TB & TB \\
& pH & 5,4 & 5,4 & 5,4 & 5,4 & 5,4 & 5,4 \\
\hline
\end{tabular}




\begin{tabular}{|c|c|c|c|c|c|c|c|}
\hline & Time dries (minutes) & 21 & 21 & 21 & 21 & 22 & 23 \\
\hline & Viscosity (cp) & 11773 & 11773 & 11773 & 11773 & 11773 & 11773 \\
\hline & Color & $\mathrm{TB}$ & $\mathrm{TB}$ & TB & TB & TB & TB \\
\hline & Smell & TB & $\mathrm{TB}$ & TB & TB & TB & TB \\
\hline \multirow[t]{5}{*}{$\mathrm{F} 1$} & $\mathrm{pH}$ & 5,6 & 5,6 & 5,6 & 5,6 & 5,6 & 5,6 \\
\hline & Time dries (minutes) & 23 & 23 & 24 & 24 & 24 & 25 \\
\hline & Viscosity (cp) & 27540 & 31240 & 31320 & 31390 & 32440 & 33350 \\
\hline & Color & TB & TB & TB & $\mathrm{TB}$ & $\mathrm{TB}$ & $\mathrm{TB}$ \\
\hline & Smell & $\mathrm{TB}$ & $\mathrm{TB}$ & TB & TB & TB & TB \\
\hline \multirow[t]{5}{*}{$\mathrm{F} 2$} & $\mathrm{pH}$ & 5,7 & 5,7 & 5,7 & 5,7 & 5,7 & 5,7 \\
\hline & Time dries (minutes) & 22 & 22 & 23 & 23 & 23 & 24 \\
\hline & Viscosity (cp) & 26490 & 27230 & 27850 & 28740 & 31290 & 31790 \\
\hline & Color & TB & TB & TB & $\mathrm{TB}$ & TB & $\mathrm{TB}$ \\
\hline & Smell & TB & $\mathrm{TB}$ & $\mathrm{TB}$ & TB & TB & TB \\
\hline \multirow[t]{5}{*}{ F3 } & $\mathrm{pH}$ & 5,5 & 5,5 & 5,5 & 5,5 & 5,5 & 5,5 \\
\hline & Time dries (minutes) & 23 & 23 & 24 & 24 & 24 & 25 \\
\hline & Viscosity (cp) & 26720 & 27640 & 28320 & 31170 & 32330 & 32440 \\
\hline & Color & TB & TB & TB & $\mathrm{TB}$ & $\mathrm{TB}$ & $\mathrm{TB}$ \\
\hline & Smell & TB & $\mathrm{TB}$ & TB & $\mathrm{TB}$ & $\mathrm{TB}$ & $\mathrm{TB}$ \\
\hline \multirow[t]{3}{*}{$\mathrm{F} 4$} & $\mathrm{pH}$ & 5,8 & 5,8 & 5,8 & 5,8 & 5,8 & 5,8 \\
\hline & Time dries (minutes) & 25 & 25 & 26 & 26 & 26 & 27 \\
\hline & Viscosity (cp) & 28810 & 29260 & 30920 & 32010 & 32650 & 33090 \\
\hline \multirow[t]{5}{*}{ F5 } & Color & $\mathrm{TB}$ & $\mathrm{TB}$ & $\mathrm{TB}$ & TB & TB & TB \\
\hline & Smell & $\mathrm{TB}$ & TB & TB & TB & $\mathrm{TB}$ & $\mathrm{TB}$ \\
\hline & $\mathrm{pH}$ & 5,7 & 5,7 & 5,7 & 5,7 & 5,7 & 5,7 \\
\hline & Time dries (minutes) & 27 & 27 & 28 & 28 & 28 & 29 \\
\hline & Viscosity (cp) & 32620 & 34750 & 35120 & 37620 & 38010 & 38240 \\
\hline F6 & Color & TB & TB & TB & TB & TB & TB \\
\hline
\end{tabular}




\begin{tabular}{lllllll}
\hline Smell & TB & TB & TB & TB & TB & TB \\
pH & 5,7 & 5,7 & 5,7 & 5,7 & 5,7 & 5,7 \\
Time dries (minutes) & 27 & 27 & 27 & 28 & 28 & 29 \\
Viscosity (cp) & 31030 & 31860 & 33790 & 34810 & 35730 & 37060 \\
\hline
\end{tabular}

Information:

TB = Not changed

$\mathrm{B}=$ Change

The observation results of peel-off gel mask showed that the color and odor of the mask preparation did not change during 12 weeks of storage at room temperature. Observations can be seen in Appendix 1.

The results of the observation of the viscosity of the peel-off gel mask during 12 weeks storage showed that the preparation had increased viscosity. This can be caused by long storage, so that old preparations are affected by the environment such as air (Black, et al., 1997).

The increase in viscosity during storage was also caused by the water in the preparation being ab-sorbed by the gelling component so that the addition of gel volume (Zatz et al., 1994). The test time of the preparation dried was done by observing the time needed for the preparation to dry, ie the time from when the peel-off gel mask was applied to the skin of the arm with a length of $7 \mathrm{~cm}$ and a width of $7 \mathrm{~cm}$ to form a dry layer. The most influential factor on dry time is the concentration of ethanol in the formulation. Increasing ethanol concentration will shorten the dry time of the preparation.It's appear because ethanol has a higher level of volatility compared to pure water (Beringhs et al., 2013). The results indicated that the longer storage time, the time preparation of peel-off gel masks to dry up increases. This can be caused by ethanol which evaporates when the packaging was opened too long during testing. Ethanol in the peel off gel mask formula serves to speed up the drying time of the mask, so that when ethanol evaporates it will give effect to the preparation in the form of increased for dry time up for longer. One factor that must be considered that the packaging should be tightly closed in order to maintain the preparation from the effects of environmental changes that can reduce the quality (Beringhs et al., 2013).

\section{Discussions}

After observing the viscosity stability test of peel off gel mask, the next step was statistical test analysis using SPSS (Statistical Package for the Social Sci-ences) 16.0 software using parametric one way ANOVA (Analysis of Variance) analysis method at $95 \%$ confidence level and continued with the Dun-can test to find out whether the viscosity stability test can change significantly.

The results of the statistical analysis of the vis-cosity stability test of the six formulas of peel off gel mask using one-way ANOVA method with a 95\% confidence level showed a significant differ-ence between each formula ( $\mathrm{P}$ value $<0.05)$. This shows that there is a difference in the gelling prop-erties of the biopolymer agent which affects the viscosity level 
of the gel peel off mask. The highest viscosity of F5 (Chitosan: Xanthan gum $38240 \mathrm{cp}$ ) and the lowest on F2 (Carboxymethyl Cellu-lose31790 cp).

\section{Conclusion}

1. The combination of biopolymer can be formulated in the dosage form of peeled gel mask. Biopolymers are Chitosan, Xanthan gum and Carboxymethylcelulos

2. The single and combination biopolymers have different viscosity effects in the preparation of exfoliating gel masks. The single biopolymer has the highest viscosity was Xanthan gum with $33350 \mathrm{cp}$. The second viscosity result was Chitosan $32440 \mathrm{cp}$ so that the lowest viscosity was Carboxymethylcelulosa with $31790 \mathrm{cp}$. The highest viscosity results of the combination of biopolymer were Chitosan + Xanthan gum which was 38240 cpupun the second was Chitosan + Carboxymethyl Cellulose with a yield of $37060 \mathrm{cp}$ and the lowest viscosity result was xanthan gum + Carboxymethyl Cellulose $33090 \mathrm{cp}$. Data obtained from one-way ANOVA results with a 95\% confidence level showed that each formula showed a significant difference $(\mathrm{P}<0.05)$, namely the highest viscosity $\mathrm{F} 5$ (Chitosan + Xanthan gum $38240 \mathrm{cp}$ ) and the lowest on F2 (Carboxymethylceluloseie $31790 \mathrm{cp})$

\section{References}

[1]Agoes, G. 2006. Pengembangan Sediaan Farmasi. Bandung: ITB. Hal. 44

[2]Birck, C., Degoutin, S., Tabary, N., Miri, V., danBacquet, M. 2014. New crosslinked cast films based on poly (vinyl alcohol): preparation and physico-chemical properties. Express Polymer Letters. 8 (12)

[3]Darmawan, A.B. 2013. Anti-Aging Rahasia Tampil Muda di Segala Usia. Yogyakarta: Media Pressindo. Halaman 8, 18.

[4]Ditjen POM RI. 1979. Farmakope Indonesia.Edisi tiga. Direktorat Jendral POM RI. Jakarta : Departemen Kesehatan Republik Indonesia. Halaman 33.

[5]Grace, F.X., Darsika, C., Sowmya, K.V., Suganya, K., danShanmuganathan. S. 2015. Preparation and Evalu-ation of Herbal Peel Off Face Mask. American Journal of PharmTech Research. (5)

[6]Harry, Ralph G. 1973. Harry's Cosmetology.EdisiKeenam. New York : Chemical Publishing Co, Inc.

[7]Jeeva, S., Mohan, T.S., Palavesan, A., Lekshmi, N.C.J.P., danBrindha, J.R.2011. Production and optimizion study of novel ekstracelluler polysaccharide by wild-type isolates of Xanthomonascampestris. Journal of Microbiologyand Biotechnology Research. 1 (4): $175-182$.

[8]Kamal, N. 2010. Pengaruh Bahan Aditif Cmc (Carboxyl Methyl Cellulose) Terhadap Beberapa Parameter Pada Larutan Sukrosa. Jurnal Teknologi. Vol. 1. Edisi 17: 78-84

[9]Martien, R., Adhyatmika., Irianto, I.D.K., Verda, F., Sari, P.S. 2012. Perkembangan Teknologi Nanopartikel Sebagai Sistem Pengantaran Obat. Majalah Farmaseutik. 8 (1): $133-14$

[10]Morris, K. 1993. Depilatories Mask Scrubs and Bleaching Preparation.Paucher's Perfumes Cosmetics and Soaps Hieda Butler.Chapman and Hall. London.

[11]Muliyawan, D., dan Suriana, N. 2013. A-Z Tentang Kosmetik. Jakarta: PT Elex Media Komputindo. Halaman 14, 16 - 17, 21 - 25, 141 - 142, 312. 
[12]Muzzarelli, R.A.A. 1985. Chitin in the Polysaccha-rides.vol.3.pp. 147.Aspinall (ed) Academic press Inc. Orlando, San Diego

[13]National Health Surveillance Agency. 2005. Cosmetic Products Stability Guide. Brazil: ANVISA. Halaman 19.

[14]Peckham, M. 2014. At a Glance Histologi. Jakarta: Penerbit Erlangga. Halaman 49,51.

[15]Pertiwi, P.L. 2012. Formulasi Masker Gel Peel Off Ekstrak Bongkahan Gambir (uncaria gambir Roxb.) dengan Basis Kitosan dan Polivinil Alkohol (PVA). Skripsi. Jakarta : Fakultas Kedokteran dan Ilmu Kesehatan, UIN Syarif Hidayatullah Jakarta.

[16]Pulungan, M.A. 1994. KajianPerkembanganPerdagangan Gum Xanthan SebagaiBahanPengentalUntuk Industry Pangan Di Indonesia.Skripsi. Bogor: Fakultas Teknologi Pertanian. Institut Pertanian Bogor.

[17]Putro, D.S. 1997. Agar AwetMuda.Purwodadi: Trubus-Agrisarana. Halaman 2 - 3.

[18]Rawlins, E.A. 2003.Bentley's Textbook of Pharmaceutics. 18th ed. London:Bailierre Tindall. Halaman 355.

[19]Rieger. 2000. Harry's Cosmetology 8thEdition.New York: Chemical Publishing Co.Inc. Halaman $471-483$.

[20]Rowe, R.C., Sheskey P.J., dan Quin, M.E. 2009. Hand-book of PharmaceuticalExcipients6th ed. Washington D.C: Pharmaceuticals Press. Halaman 283, 441.

[21]Santosa, D., dan Didik, G. 2001. Ramuan Tradisional Untuk Penyakit Kulit. Jakarta : Penerbit Swadaya.

[22]Septiani, S., Wathoni, N., dan Mita, S. 2011. Formulasi Sediaan Masker Gel Antioksidan dari Ekstrak Etanol Biji Melinjo (Gnetum Gnemon Linn). Jurnal. Bandung : Fakultas Farmasi Universitas Padjajaran.

[23]Suhardi. 1992. Khitin dan Khitosan. PusatAntarUniversi-tas Pangan \&Gizi. Yogyakarta: Universitas Gadjah Mada.

[24]Sukamto. 2010. Perbaikan tekstur dan sifat organoleptik roti yang dibuat dari bahan baku tepung jagung dimodifikasi oleh gum xanthan. Jurnal Agrika. 4 (1), 54-59.

[25]Tang ZX, Shi LE, Qian JQ. 2007. Neutral Lipase from Aqueous Solutions on chitosan Nano-Particles.Biochemichal Engineering Journal. 34: 217-223

[26]Tiyaboonchai, W. 2003. Chitosan Nanoparticel: a Promis-ing System for Drug Delivery. Naresuan University Journal. 11 (3): 51-66

[27]Tranggono, R.I., danLatifah, F. 2007.BukuPeganganIlmuPengetahuanKosmetik.Jakarta: PT.GramediaPusakaUtama. Halaman $11-32,167$.

[28]Vieira, R.P,. Fernandes, A.R., Kaneko, T.M., Consiglieri, V.O., ClaudinéiaAparecida Sales de Oliveira Pinto, Pereira, C.S.C., Baby, A.R., Velasco, M.V.R. 2009. Physical and Physicochemichal Stability Evaluation Of Cosmetic Formulation Containing Soybean Extract Fermented by Bifidobacterial Animals. Brazilian Journal of Pharmaceutical Sciences.Vol.45.Diakses 3 juli September 2009.

[29]http://www.scielo.br/pdf/bjps/v45n3/18.pdf

[30]Voigt, R. 1994. Buku Pelajaran Teknologi Farmasi. Edisi Kelima. Yogyakarta: Gajah Mada University Press. Halaman 170.

[31]Wasitaatmadja, S.M. 1997. PenuntunIlmuKosmetikMedik. Jakarta: UI-Press. Halaman $2-4,16-21$.

[32]Wibowo, D.S. 2008. Anatomi Tubuh Manusia. Jakarta: Penerbit Grasindo.

[33]Winarno, F.G. 1994. Bahan Tambahan Makanan. Jakarta: Gramedia Pustaka Utama. 
[34]Yang, J. M., Yang, S. J., Lin, H. T., Wu, T. H., \& Chen, H. J. 2008. Chitosan containing PU/Poly(NIPAAm) thermosensitive membrane for wound dressing. Mate-rials Science and Engineering C. 28 (1): 150-156.

[35]Yeom, G., Yun, D.M., Kang, Y.W., Kwon, J.S., Kang, I.O, dan Kim, S.Y. 2011.Clinical efficacy of facial masks containing yoghurt and OpuntiahumifusaRaf.(FYOP).Journal cosmetSci. 62 (5)

[36]Yulin, Happy R. 2015. Uji Stabilitas Fisik Gel Masker Peel Off Serbuk Getah Buah Pepaya (Carica Papaya L.) dengan Basis Polivinil Alkohol Dan Hidroksipropil Metilselulosa. skripsi . Jakarta : Fakultas Kedokteran dan Ilmu Kesehatan, UIN Syarif Hidayatullah Jakarta.

[37]Zath, J. L., and Kushla, G. P. 1996. Gels, in Lieberman, H. A., Lachman, L., and [38]Schwatz, J. B. Pharmaceutical Dosage Form: Dysperse System. Vol. 2.2nd Ed, P.399-

417. New York: Marcell Dekker, Inc 